\title{
21
}

\section{A Typological Overview of Aymaran and Quechuan Language Structure}

Willem F. H. Adelaar

\section{Introduction}

The present chapter seeks to provide a typological profile of the Aymaran and Quechuan languages, the main surviving indigenous language groups of the Central Andean region. ${ }^{1}$ The latter is defined here as an area of civilization characterized by a strong cultural identity and a high level of political organization and artistic achievement that covered the central and most populated areas of the South American Pacific coast and the Andean mountain range before the European invasion. In modern political terms, this area includes the coastal and Andean sectors of Bolivia, Ecuador and Peru, as well as the northern half of Chile and the northwestern part of Argentina (see Map 21.1).

Although agricultural and pastoralist beginnings in this region hark back to a much earlier time, centres of influential cultural radiation featuring monumental architecture developed during the third millennium BC in the so-called Norte Chico ('Little North') region of presentday Peru, situated near the Pacific coast, north of the capital Lima (Moseley 2001; Mann 2005). These centres were succeeded by a long sequence of local cultural developments, some of which acquired considerable regional influence in the religious and artistic domain. One influential local culture, Chavín, attained its apogee between 800 BC and 200 BC. It was centred around an important archaeological site at Chavín de Huántar, in the interior of the Andean department of Ancash, and entertained ties with both coastal and pre-Andine Amazonian settlements and populations (Burger 2008, 2012).

Although there is no linguistic documentation from these early times, there can be little doubt that the on-going proliferation of local cultural developments was reflected by a substantial amount of linguistic diversity, as can be noted in other regions of the New World with ancient agricultural roots, such as Colombia and Mexico. In the Central Andes, this 


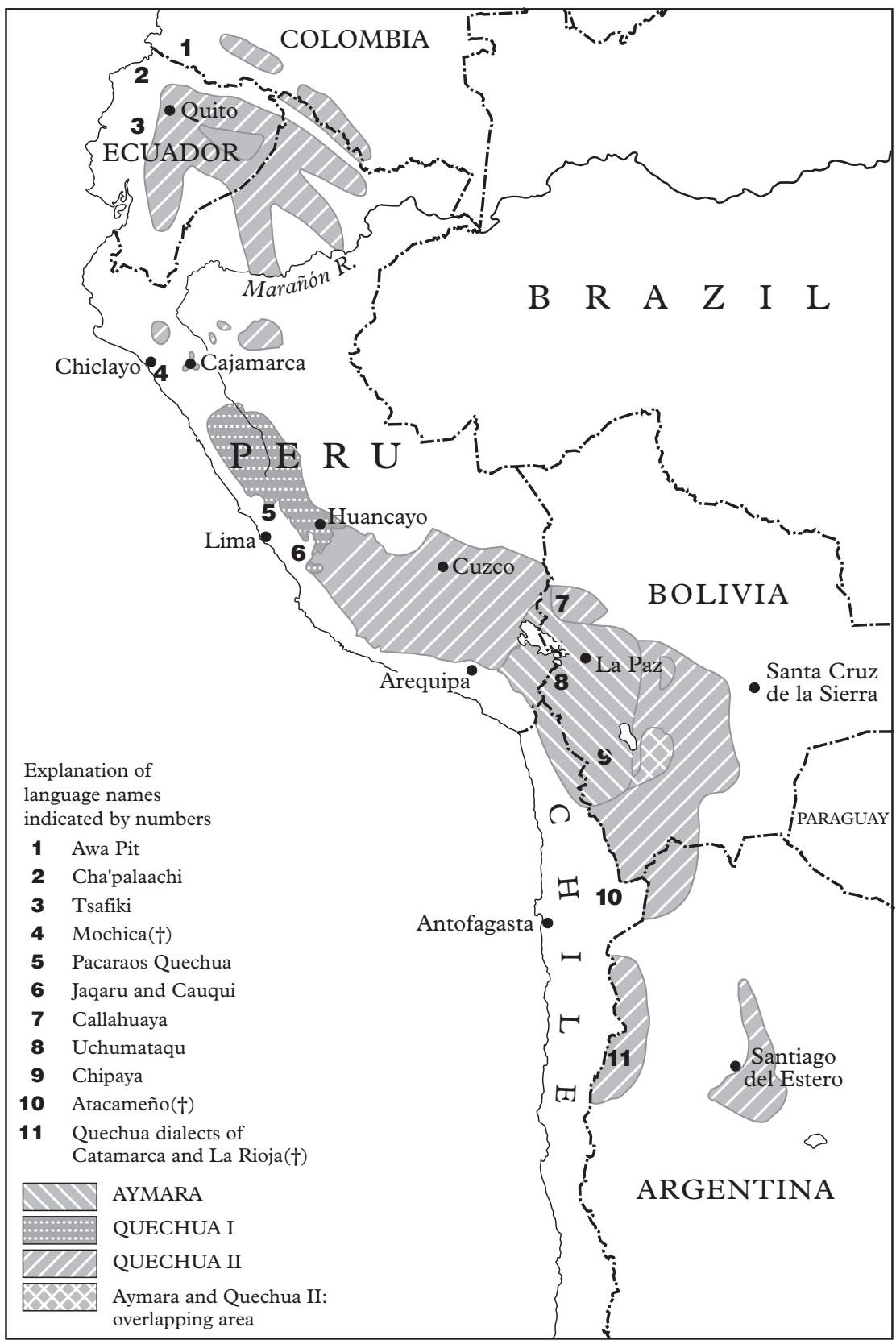

Map 21.1 Aymaran and Quechuan languages. (C) W. F. H. Adelaar, previously published in The Languages of the Andes: 169 ed. Willem Adelaar and Pieter C. Muysken

diversity clearly came under pressure around AD 500-600 when powerful states emerged, such as the Huari state, centred near the present-day town of Ayacucho in the central-southern Andes of Peru, and Tiahuanaco, associated with the monumental religious centre of the same name on the 
Bolivian Altiplano. Both political entities achieved considerable territorial expansion, either by military occupation or by the establishment of population colonies in newly conquered areas. The ultimate unification of the Central Andean region was achieved by the Incas of Cuzco in the fifteenth and early sixteenth centuries. Their ultimate prowess was the conquest of highland Ecuador, a region that had until then remained relatively separate from the areas under central Peruvian influence further south. It is during these final years of Inca expansion that the Central Andean cultural region achieved its greatest extension and unification. Accordingly, the external boundaries of the Inca Empire (Tawantinsuyu, 'Land of Four Quarters' in Southern Peruvian Quechua) at the time of the Spanish conquest are often taken as the limits of a putative Central Andean culturallinguistic area.

Colonial sources, as well as toponymy and local vocabulary, point to the existence of considerable diversity, both genealogical and typological, among the languages of the Central Andes in early historical times. Nevertheless, the existing documentation of Central Andean languages is overwhelmingly concentrated on the Aymaran and Quechuan languages, two language families with an internal diversification that probably does not exceed 2,000 years. In non-specialized circles, the totality of Quechuan linguistic varieties is often referred to as a single language, denominated Quechua, with scores of local dialects named after the administrative areas or towns where they are spoken (e.g. Bolivian Quechua, Ancash Quechua, Cuzco Quechua, etc.). The Aymaran family is represented by two surviving languages: Aymara and Jaqaru (including the neighbouring Kawki variety). ${ }^{2}$ These two languages are often referred to as Southern Aimara and Central Aimara, respectively (Cerrón-Palomino 2000). ${ }^{3}$

Conservative varieties within these two families largely feature the same typological characteristics and are structurally very similar (cf. Cerrón-Palomino 2008). This is almost certainly due to a process of intense linguistic interaction which may have begun as early as the beginning of the present era and that probably continued at local and regional levels in the centuries that followed. In spite of assertions to the contrary (most prominently by Orr and Longacre 1968), the Aymaran and Quechuan languages are not demonstrably related in a genetic sense. From a typological point of view, however, they present so many similarities at all linguistic levels that a combined treatment of the two groups is justified. ${ }^{4}$ Meanwhile, some non-conservative Quechuan languages, in particular the varieties of Ecuador, underwent a process of creolization that moved them away from the average language type represented by the Aymaran and Quechuan languages. This may have occurred under the influence of languages that pre-dated the introduction of Quechuan in the areas in question (Ciucci and Muysken 2011).

As a result of an on-going debate on the origins of the Aymaran and Quechuan lineages and the nature of their convergence, it is no longer 
usual to assign rigidly separate areas to the two language families throughout their history (Adelaar 2012; Muysken 2012). At least during the initial and most intense period of their convergence, they must have roughly occupied the same or overlapping areas, most likely situated in the Andes of Central Peru. It appears that a predecessor of Proto-Quechua (now often referred to as Pre-Proto-Quechua) was structurally remodelled under the influence of an Aymaran substratum in a situation of intense bilingualism. A lexical borrowing influence of considerable dimensions appears to have gone in the opposite direction (Adelaar 1986; Emlen forthcoming). There are good reasons to assume that part of the interaction between the two language groups persisted throughout the centuries, in some areas until today, and that part of their expansions may have been the result of joint operations. For the same reasons a careful approach is in order when assigning an exclusive linguistic identity to particular pre-historic developments such as the Huari state, whether Aymaran (Torero 1972, 2002; Cerrón-Palomino 2000), or Quechuan (Beresford-Jones and Heggarty 2012). A multilingual situation would be in the line of expectation.

Apart from Aymaran and Quechuan, only one other language in the Central Andean highlands has survived the nearly five centuries of European colonization. This language, spoken in a village on the Bolivian high plateau, is Chipaya, the last surviving representative of the Uru-Chipaya family. It has been fairly well documented in recent years (Cerrón-Palomino 2006; Cerrón-Palomino and Ballón Aguirre 2011). In spite of intensive borrowing from the surrounding languages, the Chipaya language exhibits important typological differences with regard to Aymaran and Quechuan, such as the presence of an agreement system based on grammatical gender and a less elaborate personal reference system in the verb.

At the north-western fringe of the Central Andean region, in the northern Ecuadorian coastal area, three languages of the Barbacoan family are still in use: Cha'palaachi, Tsafiki and Awa Pit. ${ }^{5}$ These languages combine Central Andean characteristics with those of languages spoken further north in Colombia.

All other languages native to the Central Andean region are now extinct. Only a few of them (Mochica, Cholón, ${ }^{6}$ Atacameño, Lule, Pukina) benefit from a minimal level of documentation. This is not sufficient, however, for establishing a full typological profile of these languages.

The following pages will focus on the typological characteristics of the Aymaran and Quechuan languages.

\subsection{Structural Features of Aymaran and Quechuan}

The Aymaran and Quechuan languages represent a language type that is relatively common in the languages of the world but relatively rare 
among the languages of the Americas. ${ }^{7}$ Both language groups feature an elaborate and complex inflectional and derivational morphology which is almost entirely based on suffixation. Prefixes do not occur. Vowel modification (mostly vocalic lengthening) plays a relatively modest role in Aymaran morphology and in that of the Central Peruvian Quechuan branch. ${ }^{8}$ In addition, vowel suppression as an inherent feature of affixes plays an unusually prominent role in the Aymaran languages, but it is not normally found in Quechuan. ${ }^{9}$ Vowel deletion for morphosyntactic purposes (for instance, in order to mark accusative case) is also a frequent phenomenon in modern Aymara. Another prominent feature of the morphology of both Aymaran and Quechuan is its great regularity.

Reduplication and repetition play a significant role in the creation of expressive language, both at the level of root formation and in more complex phrases. These phenomena are particularly frequent in the Quechuan languages. Compounding is mostly limited to nominal expressions that consist of juxtaposed elements retaining their characteristics as phonological words, in particular, word stress. True nominal compounds, in which the constituents no longer preserve the characteristics of separate words do occur, but are rather exceptional. The constituent order in nominal compounds is modifier-modified, which is also the prevalent word order in noun phrases in general in these languages. Verbs do not normally participate in compounding. There are no verbal compounds, nor serial verbs. Noun incorporation is non-existent.

In both Aymaran and Quechuan, there is a rather strict division between verbal morphology and nominal morphology. Verbs are easy to single out because they cannot occur without the proper inflectional affixes. Nouns, pronouns, adjectives and adverbs need not be followed by affixes..$^{10}$ They generally draw from a single reservoir of affixes and modifications that together make up the nominal morphology. There is hardly any overlap between verbal and nominal morphology, except in the sphere of personal reference marking, where homophonous affixes function in both systems. By contrast, there are plenty of mechanisms facilitating the transposition of verbal bases to the nominal class and vice versa. It is not unusual to find successive instances of nominalization and verbalization in a single word form, especially in Aymara.

In addition to the specific nominal and verbal morphology, the languages of both families also feature a set of affixes that function at the level of sentences or sentence constituents. These elements are often referred to in the literature as 'clitics' or 'sentential affixes'. They are completely integrated in the phonological word, which in most instances is characterized by penultimate stress. Many Quechuan varieties also have a small set of true clitics which are not fully incorporated in the phonological word. Sentential affixes and true clitics can be attached to noun 
phrases, subordinate clauses, verbs and other sentential constituents except for some restrictions.

The usual order of constituents in Aymaran and Quechuan complement clauses, including nominalized and subordinate clauses, is subject-objectverb (S/A-O-V). The same preference holds for the sentence level, where other constituent orders are nevertheless tolerated. Most Aymaran and Quechuan languages strictly adhere to the rule that modifiers must precede the modified. There is a significant exception, however. In Quechuan languages, relative clauses that are constructed on the basis of a nominalized verb can follow their antecedent, and in some circumstances this is compulsory (see below).

\subsection{Alignment}

The Aymaran and Quechuan languages are characterized by a nominativeaccusative alignment pattern. The role of agent or subject in a sentence or clause remains unmarked, but all other complements are normally marked for case, except for the nominal complement of the copula ka'to be' in Quechuan. In the Aymaran languages, which have no verb 'to be', the function of the copula is encoded morphologically, either by vowel lengthening (in Aymara) or by a segmental affix (in Jaqaru). With a third person singular subject in the unmarked tense and mood, the copula position (in Quechuan) and the morphological encoding (in Aymaran) are usually empty, so that only the nominal complement remains.

A salient feature of the Aymaran and Quechuan languages is that a direct object or patient is also generally marked for case; in Quechuan it is marked by the accusative affix $-t a^{11}$ and in Aymara by suppression of the final vowel of the base, which has a similar function. ${ }^{12}$ Accusative case marking is not exclusive to human or animate patients, as it is in some other South American languages, but it is also obligatorily used with inanimate objects.

Conversely, accusative case marking is not restricted to direct objects, which makes it hard to distinguish clear patterns of transitivity in Aymaran and Quechuan. In its basic, non-derived form, a verb can be either transitive or intransitive. None of the morphosyntactic criteria that in other languages serve to distinguish between transitive and intransitive verbs seem to work, as specified below:

a. Subject and patient are obligatorily cross-referenced in the verb form, except when the patient is a third person (non-SAP) argument. As a result, there is no formal distinction between a verb with a third person direct object and the same verb in its antipassive interpretation. As long as third person objects are not expressed lexically, the difference between third person object and absence of object remains ambiguous. 
b. A patient expressed in the verb form does not necessarily correspond to the direct object in a transitive construction. More decisive is its status as a Speech Act Participant (SAP) and, hence, its human or humanized nature. In a large number of cases, patient marking refers to an indirect object, a beneficiary or an experimenter, rather than to a direct object.

c. As noted above, the accusative case marker has more functions than just indicating a direct object. With verbs referring to motion (for instance, verbs for 'to go'), it indicates a geographical goal. Characteristically, a verb selects accusative case for the object or goal that is typical for its meaning, regardless of whether the latter is a direct object, an indirect object or a geographical goal. Furthermore, Quechuan languages differ in the way they distinguish between direct and indirect object. Central Peruvian Quechua I dialects use accusative case marking for both purposes, whereas most Quechua II varieties and Aymara are said to employ the allative case marker -man (Aymara -ru) for indirect objects in order to distinguish them from direct objects (cf. Cerrón-Palomino 1987: 293-4). ${ }^{13}$

d. Many Aymaran and Quechuan verbs combine transitive and intransitive functions in their basic meanings (e.g. Cuzco Quechua and Aymara p'aki- 'to break'; Central and Southern Peruvian Quechua kuti- 'to turn', 'to return'; Northern Junín Quechua, uša- ‘to finish (off)', 'to exterminate', 'to be worn down', etc.).

e. Some derivational affixes fulfil the function of increasing transitivity of a verb or enhance transitive properties when these are already present. No affixes appear to be exclusively designed to make intransitive verbs transitive. Conversely, there are also derivational affixes that have the function of reducing or removing transitivity when the latter is part of the basic verbal meaning.

f. In spite of their rich derivational morphology, Aymaran and Quechuan languages lack a morphological passive and do not have a periphrastic construction exclusively designed for that purpose. ${ }^{14}$ Some derivational affixes in Quechuan (Central Peruvian Quechua I Non-Control -ka(:)-, Southern Peruvian Quechua II Reflexive -ku-) allow a passive interpretation which is clearly parasitic on their basic meaning. Whether such an interpretation is possible depends on the meaning of the verb base to which the derivational affixes in question are added.

It will be clear from the above observations that the transitive/intransitive distinction does not play a central role in the Andean verbal lexicon. Constructions may be transitive, but verbs themselves often derive their (in)transitive character from the context or from specific morphology. 


\subsection{Case}

As noted above, all nominals (nouns and noun phrases) that function as verbal complements must be marked for case, including those that refer to a patient or direct object. Case marking is furthermore used to indicate that nouns stand in a subordinate (genitive) or coordinate (comitative) relationship vis-à-vis each other. Case markers in Aymaran and Quechuan are limited in number, and they generally have stable functions. Based on inherent semantic features, their interpretation is usually straightforward and rarely influenced by the meaning of the verb with which they co-occur. As an exception to this, the distinction between accusative -ta and allative -man in Quechuan can be somewhat fluid. In connection with verbs of motion, the former refers to a stable goal in focus, whereas the latter implies a moving goal, an unpredictable location, or a collateral goal. ${ }^{15}$ These case markers are also the only ones that can be subject to selection based on the meaning of the verb that governs them. For instance, there is a tendency for the verb 'to arrive', 'to reach' (Quechua I ĉa:-, Quechua II čaya-) to govern the allative case, whereas the verb 'to go' (Quechua I aywa-; Quechua II ri-) prefers the accusative.

There is quite a bit of geographic variation in the shape and constitution of case markers, especially in Quechuan, which suggests that their formation is of a relatively recent date. Several case markers appear to be historically derived from sequences of other case markers. In these cases the second element is homophonous with the accusative marker -ta, suggesting that the latter developed from a marker for oblique relations in general. ${ }^{16}$ Examples are the Quechua II ablative marker -manta, which besides - $t a$ may contain the allative suffix -man, and the Quechua I ablative marker -pita, which may comprise the locative case marker -pi still found in Quechua II. ${ }^{17}$ Also in Quechuan, productive (non-historical) combinations of case markers occur, in which each marker retains its original meaning (e.g. - pa-ta genitive + accusative, -ta-wan accusative + comitative). By contrast, the Aymaran set of case markers looks like a reduced version of the Quechuan one. There are no case markers derived from sequences of markers as in Quechuan. Locative and genitive case are both encoded by a single case marker -na, ablative case by a non-compositional marker $-t^{h} a$.

Since Aymaran and Quechuan do not have an agreement system, case is normally marked only once, namely, on the last (or sole) lexical constituent of a nominal phrase. Nevertheless, disjunction of the lexical constituents in a nominal construction can be obtained by manipulating the word order or by highlighting one of the constituents by prosodic means. The unity of the noun phrase is then indicated by marking each of the disjoined elements with the same case marker (usually -ta). A similar technique is used in coordinate nominal constructions, in which each of the coordinated elements is marked for the same case. The final element in a 
hierarchically organized nominal construction that receives case marking is usually the head of that construction but not always. In several Quechuan languages, a nominalized verb can act as a relative clause while it is located after the antecedent. In that case it receives the case marking pertaining to the antecedent, which itself remains unmarked for case.

\subsection{Personal Reference}

The encoding of grammatical person takes up a central position in the morphology of Aymaran and Quechuan verbs. It obligatorily identifies the verb's subject and frequently also that of a human (or humanized) SAP patient. Substantives and most other nominal expressions, not including bare adjectives, can also be marked for grammatical person, in which case it refers to a possessor or to the holder of any other relation equivalent to possession (family relationship, part-whole relations, spatial relations, identification in general, etc.). These possessive endings no longer occur in the Ecuadorian varieties of Quechuan.

The main grammatical categories of person that can be established for Aymaran and Quechuan are four in number. They can be defined in terms of the inclusion of the speaker and the addressee: 1 [+Speaker, -Addressee], 2 [-Speaker, +Addressee], 3 [+Speaker, -Addressee], and 4 [+Speaker, +Addressee] (Hardman, Vásquez and Yapita 1988: 18; Adelaar and Muysken 2004: 211). In this original system, the inclusive/exclusive distinction is expressed indirectly by exploiting the opposition between first (exclusive) and fourth (inclusive) person, and it is best preserved in the Aymaran languages and the Quechua I branch of the Quechuan languages. In the Quechua II languages of Southern Peru, Bolivia and Argentina, personal reference marking has become intertwined with the expression of grammatical number (see below). As a result, some of these varieties have developed true first person plural exclusive endings that stand in opposition with the inclusive endings represented by the original fourth person. At the opposite end of the spectrum embodied by these highly complex systems of person and number marking, the Quechua II varieties spoken in Ecuador have lost the inclusive/exclusive opposition and preserve the original inclusive forms for the expression of first person plural in general.

As was noted before, subject and patient are obligatorily expressed in the verb form, except when the patient is third person. As a rule, conservative Quechuan varieties, as well as Aymara, present paradigms with nine basic endings: $1(>3), 2(>3), 3(>3), 4(>3), 1>2,2>1,3>1,3>2,3>4 .{ }^{18}$ The existence of an additional combination, $4>2$, has been reported for Jaqaru (Hardman 1966: 47ff.). By contrast, Ecuadorian Quechua only retains 
Table 21.1 Personal reference paradigms in La Paz Aymara (based on Yapita 1991)

\begin{tabular}{|c|c|c|c|}
\hline & Present tense & Future tense & Present potential \\
\hline $1 \mathrm{~A} / \mathrm{S}[>3 \mathrm{O}]$ & $-[\mathrm{C}] \mathrm{t}(\mathrm{a})$ & $-\mathrm{V}:$ & -irist(a) \\
\hline $2 \mathrm{~A} / \mathrm{S}[>30]$ & $-[C]$ ta & -V:ta & -sma \\
\hline $3 \mathrm{~A} / \mathrm{S}[>30]$ & $-i$ & $-n i$ & -spa \\
\hline $4 \mathrm{~A} / \mathrm{S}[>30]$ & $-[C] \tan$ & $-n^{y}$ ani & $-[C] s n a$ \\
\hline $1 \mathrm{~A} / \mathrm{S}>20$ & $-[C]$ sma & $-\mathrm{V}: \mathrm{ma}$ & -irisma \\
\hline $2 \mathrm{~A} / \mathrm{S}>10$ & -ista & -ita:ta & -itasma \\
\hline $3 \mathrm{~A} / \mathrm{S}>10$ & -itu & -itani & -itaspa \\
\hline $3 \mathrm{~A} / \mathrm{S}>20$ & $-[C]$ tam & -V:tam & -iristam \\
\hline $3 \mathrm{~A} / \mathrm{S}>40$ & -istu & -istani & -(i)staspa \\
\hline
\end{tabular}

$[C]$ indicates that the final (short) vowel of the preceding element is suppressed. Before initial $-i$ - the final vowel of the preceding element is not preserved. $V$ : indicates that the final vowel of the preceding element is lengthened.

(a): This vowel is suppressed before clitics.

forms that encode a subject alone as well as those that express a subject combined with a first person patient $(2>1,3>1)$.

The Aymaran languages present a high degree of fusion in their personal reference endings, which makes it nearly impossible to segment them unequivocally into meaningful components. Even when consisting of several syllables, these endings cannot be interrupted by other morphological material. They can vary according to tense and mood, the future and imperative paradigms being notoriously different from all the others in terms of personal reference marking. The complexity of the personal reference paradigms distributed over tense, mood and evidentiality, as well as the sheer number of unanalysable forms involved, represent a serious burden on the memory of a learner of an Aymaran language, who will find it difficult to master all the forms and their functions (Table 21.1). It is noteworthy, however, that these complex personal reference markers cannot be attached to nominalized verbs. Personal reference marking on nominalized verbs is restricted to the nominal possessive endings, and the roles of subject and patient are not kept apart.

Personal reference endings in the Quechuan languages present features similar to those found in Aymaran, but there are noticeable differences that make the Quechuan endings more transparent and more flexible in their combinatory possibilities. In Quechuan, the personal endings that specify only a subject and the ending that indicates a transition from speaker to addressee (1>2) are generally undividable, but all other endings involving reference to a patient consist of combinations of affixes that can occur jointly or be separated by a marker of tense, subordination or nominalization. These combinations consist of a fixed verb-internal part (preceding any tense markers, etc.) and a changeable verb-external part (following any tense markers, etc.) that can vary according to tense and mood. These 
Table 21.2 Reconstructed personal reference paradigms in Quechuan

\begin{tabular}{|c|c|c|}
\hline & \multicolumn{2}{|c|}{ Non-separable (direct) endings } \\
\hline & Non-future & Future \\
\hline $\begin{array}{l}1 \mathrm{~A} / \mathrm{S}[>3 \mathrm{O} \\
1 \mathrm{~A} / \mathrm{S}>2 \mathrm{O} \\
2 \mathrm{~A} / \mathrm{S}[>3 \mathrm{O} \\
3 \mathrm{~A} / \mathrm{S}[>3 \mathrm{C}] \\
4 \mathrm{~A} / \mathrm{S}\left[\begin{array}{ll}> & 0\end{array}\right]\end{array}$ & $\begin{array}{l}\text {-v́://-V́y//-y/-ni } \\
-q / /-y k i / /-k \\
-n k i /-y k i \\
-n /-\varnothing \\
\text {-nčik }\end{array}$ & $\begin{array}{l}\text {-šaq } \\
\text {-šqayki } \\
\text {-nki } \\
\text {-nqa } \\
\text {-šun }\end{array}$ \\
\hline \multirow{2}{*}{$4 \mathrm{~A} / \mathrm{S}[>3 \mathrm{O}]$} & \multicolumn{2}{|c|}{ Separable (inverse) endings } \\
\hline & Non-future & Future \\
\hline $\begin{array}{l}2 \mathrm{~A} / \mathrm{S}>10 \\
3 \mathrm{~A} / \mathrm{S}>10 \\
3 \mathrm{~A} / \mathrm{S}>20 \\
3 \mathrm{~A} / \mathrm{S}>40\end{array}$ & $\begin{array}{l}\text {-ma(:)-//-wa- + -nki/-(y)ki } \\
\text {-ma(:)-//-wa- + -n/-ø } \\
\text {-šu- + -nki/-(y)ki } \\
\text {-ma(:)-//-wa- + -nčik }\end{array}$ & $\begin{array}{l}\text {-ma(:)-//-wa-nki } \\
\text {-ma(:)-//-wa-nqa } \\
\text {-šu-nki } \\
\text {-ma(:)-//-wa-šun }\end{array}$ \\
\hline
\end{tabular}

// geographical variation

/ paradigmatic variation

+ possibility to insert affixes (tense, subordination, nominalization)

changeable external elements are identical in form (but not necessarily in meaning) with the personal reference markers that refer to subject only. The fixed internal elements can either represent a straightforward patient marker (Quechua I -ma(:)- / Quechua II -wa-1st person patient), or an inverse marker indicating that the changeable external element refers to a patient, rather than to the subject (the actor being 3rd person in these cases). As a rule, there are two inverse markers, - šu- - -su-,${ }^{19}$ indicating a reversal of the role of the second person (3>2), and again -ma(:)- $-1-w a-$, which refers to a similar reversal for the inclusive person $(3>4)$.

The above holds for the most conservative Quechuan languages (e.g. Quechua I, Quechua IIC Ayacucho, etc.), but in several outlier varieties there is a tendency for the inverse marker -šu-|-su- to become a straightforward second person patient marker. Characteristically, such a replacement occurs at a position in a verbal paradigm where it is particularly useful, leaving other positions unaffected for the time being, or the replacement may be generalized throughout several or all verbal paradigms. In this way, Cajamarca Quechua, like Southern Bolivian and Argentinian Quechua, distinguishes between $3>2$ future tense -šu-nqa as opposed to $3>2$ present tense -šu-nki, whereas originally both combinations were represented in an identical way as -šu-nki. In Cajamarca Quechua, -šu- can also be used to reinforce or disambiguate the second person patient element in a $1>2$ marker, as in rika-rqa-q rika-šu-rqa-q 'I saw you' (Quesada 1976: 126).

As can be expected, the free (lexically expressed) personal pronouns in Aymaran and Quechuan reflect the previously outlined four-person system. Of the Aymara pronouns naya 'I', huma 'you', hupa 'he, she', and hiwasa 
'we (inclusive)', three appear to be derived from a common root augmented with the possessive endings -ma (2nd), -pa (3rd) and -sa (4th). Similarities with the verbal personal reference endings (especially those of the imperative mood and future tense) are sporadic. In the Quechuan languages, there are only three basic personal pronouns, e.g. Ayacucho Quechua $n^{y}$ uqa 'I', qam 'you', and pay 'he, she'. The inclusive form $n^{y} u q a n c ̌ i k$ was clearly derived from the first person pronoun expanded with the fourth person possessive suffix -nčik. Remarkably, there is no other similarity of any significance between the free pronouns in Quechuan and the personal reference endings to which they correspond.

\subsection{Plural Marking}

Plural marking (pluralization) is found in both the verbal and the nominal morphology. Pluralization of substantives and other nouns, including the pronouns, is realized in a straightforward way by means of affixes such as -naka (Aymara) and -kuna (Quechuan and Jaqaru). By contrast, the pluralization of verbs and personal reference markers is complex and diverse, especially in the Quechuan languages. The different pluralization strategies found in these languages seem to indicate a relatively recent origin, as they cannot be reconstructed to the Quechua proto-language, nor to the proto-languages of the two main branches of the family.

In Aymara and in the Quechua I languages of Central Peru pluralization of the subject (and occasionally of a patient) is expressed internally in the verb by means of specialized affixes. Nominal possessive affixes cannot be pluralized by morphological means in these languages. The verbal pluralizing affixes tend to interact with aspect markers (see below) and specific derivational affixes. Some varieties of Quechua I feature as many as three pluralizing affixes, the selection of which depends on the affixes (or combinations of affixes) with which they co-occur. In Pacaraos Quechua and neighbouring varieties, a portmanteau suffix -rka:ĉa(:)- represents the combination of progressive aspect -yka(:)- and Plural -ri-. In the Quechua I dialects of Junín the ending -r(q)a:ri- (and its local variants) encodes the combination of perfective aspect and plural, although -:ri- does not occur as a plural marker independently.

By contrast, most of the Quechua II dialects indicate pluralization of personal reference markers by means of affixes that are located to the right of these markers, that is, at the external boundary of the verb or noun on which they occur. The most elaborate system obtains in the Quechua IIC dialects of Southern Peru, Bolivia and Argentina, where two elements, $-k u$ and -čik (with local reflexes, -čis, -čix, -čiq, etc.), share the function of pluralizing personal reference markers that are already present. The former is used for pluralizing first and third person markers, the latter for second person. This diversified strategy makes it possible to distinguish 
between the plurality of subject and patient, at least when a second person is involved. It also facilitated the rise of a straightforward inclusive/exclusive opposition in verbal endings encoding subject and patient (cf. Adelaar 1995), as can be witnessed in (Southern Bolivian) Cochabamba Quechua (Bills, Troike and Bernardo Vallejo 1969):

$$
\begin{aligned}
& \text { a. maqa-wa-y-ku } \\
& \text { beat-1 O.I N V-1 S-P L } \\
& \text { 'He beats us (excl.)' } \\
& \text { b. maqa-wa-nchis } \\
& \text { beat-10.I N V-4s } \\
& \text { 'He beats us (incl.)' }
\end{aligned}
$$

In (1a) the affix sequence $-y$-ku (originally $1 \mathrm{~s}+$ PLU R) is best treated as a single affix $-y k u$ with the meaning first person plural exclusive because it follows the inversion pattern originally reserved for the combined $3>4$ ending (3rd person subject acts upon a 1st person inclusive patient).

\subsection{Tense, Aspect and Mood}

Although tense, aspect and mood are often treated in the literature as interrelated categories, the situation in Aymaran and Quechuan is different in that aspect is structurally and semantically separate from the other two. Categories of tense and aspect are combinable without restrictions, and the same holds for mood and aspect. By contrast, tense and mood are interrelated up to a certain degree.

Tense plays a central and straightforward role in the verbal morphology of both language groups. There is no nominal tense. In the indicative mood a division exists between future tense and all non-future tenses. Future tense has special (portmanteau) endings, except for the second person subject ending -nki (also found in the combined $3>2$ ending -šu-nki/-su-nki), which is shared by the future and the present tense in the Quechuan languages. Future is used to express any event initiated after the moment of speaking, even when the difference of time with the present is only a matter of seconds. The future has an exclusively future meaning and cannot be used to express a supposition or a conjecture as in Spanish, unless a conjectural or inferential marker is added. Future tense may nevertheless be used in commands to be carried out after the time of speaking.

All Quechuan languages also have an unmarked present tense and a past tense, which is formed by inserting a past tense affix (usually -rqa or any reflex of it) before or between the affixes of personal reference. Apart from these basic forms, most Quechuan languages also distinguish a habitual past and a sudden discovery past. These are formally compound tenses which consist of a nominalized verb form and the copula verb 'to be', 
although the latter is often optional or no longer expressed at all. The sudden discovery past is often combined with other tense-related functions such as narrative past. It is rendered in Andean Spanish as a plusquam-perfect and has been associated with the semantic notion of mirative. However, the principal function of this verbal category is not to express surprise but to communicate information that the audience was not previously aware of. ${ }^{20}$ Further tense distinctions, all pertaining to the past, developed in specific Quechuan varieties. They include categories such as recent past (as opposed to regular past), experiential past, narrative past and (non-mirative) Perfect tense. The most elaborate tense systems are found in the Northern Quechua I dialects in the Peruvian department of Ancash (Parker 1976; Hintz 2007).

The Aymaran languages exhibit a more conservative system of four tenses: future, present, and two past tenses. In addition it is possible to form a habitual past based on the re-verbalization of an agentive nominalized verb form. At least for Aymara, the remote past tense has been associated in the literature with events from a remote past that the speaker could not have personally witnessed (Hardman et al. 1988: 147). Further research is needed to establish the semantic correspondences between the Aymaran and Quechuan past tenses.

Apart from the indicative mood, which is not marked as such, most Quechuan languages distinguish a conditional or potential mood, which refers to the possibility of occurrence of an event. This mood is marked by a suffix -man, which follows the personal reference markers and, in most cases, also the external plural markers. ${ }^{21}$ It includes a present and a past form, which refers to a missed chance or a non-accomplished possibility. The past potential is constructed as a compound tense consisting of the present potential followed by the past tense form of the verb 'to be', kar(q)a. The imperative or hortative mood includes forms for all grammatical persons for second, third and (inclusive) fourth person. In Aymara the mood system is similar to that in Quechua, except that two additional distinctions related to evidentiality have to be considered as well, inferential -pača and conjectural -či ${ }^{22}$ These evidential categories do combine with the tenses and moods (Hardman et al. 1988: 148-57).

Most Quechuan languages have a verbal affix denoting progressive aspect, represented by forms such as -ckka-, -čka-, $-y(k) a-$ (or reflexes). ${ }^{23}$ This suffix can combine with any tense or mood, as well as with nominalized and subordinate verb forms. In the Quechuan dialects of the departments of Junín, Lima and Pasco (Southern Quechua I), a highly dynamic aspect system obtains consisting of the mutually exclusive categories of progressive and perfective, sometimes complemented with a third category indicating a customary event. ${ }^{24}$ Although the perfective $-r(q) u$ - has its origin in the sphere of verbal derivation (see below), Quechuan aspect markers never take part in lexicalized verb-affix combinations and their presence is near-obligatory in lively conversation or narratives (Adelaar 1988). Their 
character is flexional, rather than derivational. A slightly different and very elaborate aspect system has been recorded for the South Conchucos variety in Ancash (Hintz 2011).

In the Aymara of the Bolivian Altiplano, the main aspectual distinctions appear to evolve around a completive/incompletive opposition. Progressive aspect is indicated by means of an ending -ska-, presumably a combination of the reflexive suffix -si- and the incompletive suffix $-k a-$ (Hardman et al. 1988: 111).

\subsection{Verbal derivation}

Verbal derivation is one of the most elusive and least well understood areas of Aymaran and Quechuan grammar. Both language groups dispose of a wide array of affixes that can be used to modify the basic meaning of a verb. The semantic input and the functions of these affixes are heterogeneous. Some of them have concrete syntax-related functions, such as causative (Aym. -ya-, Qu. -či-), applicative (Qu. -pa-), benefactive (Aym. -rapi-, Qu. -pu-), reflexive (Aym. -si-, Qu. -ku-) and reciprocal (Aym. -si-, Qu. -naku-). Others modify the spatial characteristics of a verb (e.g. directional affixes) or refer to the temporal make-up of an event in an Aktionsart-type framework (stative, inchoative, iterative, etc.). Several derivational affixes also serve pragmatic purposes and may indicate attitudes of the speaker, urgency and tension, the expected involvement of the addressee, or evaluations of the importance or relevance of an event. Such affixes characteristically combine different functions pertaining to different speech styles, levels of conversation, degrees of attention, socially sensitive situations, etc. The applications and uses of derivational affixes may vary considerably from dialect to dialect.

A consequential property of verbal derivational affixes is that in combination with existing verb roots they tend to generate new verbs with derived but not fully predictable meanings. In some cases the use of a derivational affix appears to be a matter of convention and its semantic input effectively null. Modern dictionaries of Aymaran and Quechuan illustrate this problematic field as they are full of lexical entries consisting of derived verb bases containing one or more derivational affixes. This creative potential of the derivational affixes makes up for the relatively small size of the basic verbal lexicon in the Andean languages. In reference grammars and descriptive studies of the Andean languages, little attention has been paid to the creative potential of derivational affixes in the lexical domain, as semantically divergent combinations are treated as idiosyncratic formations.

Another property of verbal derivational affixes is that they may occur in combinations of affixes with specialized meanings. The order in which verbal derivational affixes occur is generally fixed but may also be partly 
determined by the degree of lexicalization and acceptance of the combinations in which these affixes participate.

The inventory of verbal derivational affixes is larger in the Aymaran languages than in the Quechuan languages. The difference resides mainly in the number of space-related distinctions that can be expressed in Aymaran but not in Quechuan. As a rule, Quechuan derivational affixes with their multiple functions are semantically more elusive than the Aymaran derivationals. An illustrative example is that of the Quechuan suffix *-rqu-, which was originally reconstructed as a directional affix for outward movement (Parker 1973: 22-3). It is still found in lexicalized verb bases such as yarqu- 'to go out, to leave' in Quechua I, but as a productive affix, whether or not in its reduced form -ru- or any other local reflex, it has such widely divergent functions as urgency (Ayacucho and Cuzco Quechua), recent past (Ancash Quechua) and perfective aspect (Junín Quechua), etc. ${ }^{25}$

\subsection{Subordination and Switch Reference}

In the Quechuan languages verbs can be marked as subordinate with regard to a main verb or another subordinate verb form. ${ }^{26}$ The default semantic interpretation of the relation between a subordinate verb and its superordinate counterpart is temporal or causal, although more complex types of relationship, such as conditionality and concession, can be expressed by attaching appropriate clitics to the subordinate verb form. The nature of the temporal relationship (either consecutive, or simultaneous) can be further refined by the inclusion of aspect markers in the subordinate verb. Note that the status of a clause headed by a verb in its subordinate form can range from that of a mere stage in an enumeration of events to that of an elaborate adverbial construction.

The subordinate verb in Quechuan is subject to a switch-reference distinction. The use of a paradigm characterized by the presence of the marker -pti- (in Ecuador -xpi) indicates that the subject of the subordinate verb is not the same as that of the superordinate verb. Personal reference marking encoding subject and, when relevant, both a subject and a patient is compulsory in connection with -pti- (though it does not occur with Ecuadorian -xpi). If the two subjects are identical, -špa/-spa is used in most of the Quechua II varieties, whereas $-r$ is the predominant marker in Quechua I. Some varieties have special forms indicating the simultaneousness of events expressed by a subordinate verb and its superordinate, but only when the subjects are identical. Otherwise simultaneousness is indicated by an aspect marker as noted before.

In the literature on Quechuan, subordinate verbs with -pti- are often described as the product of a nominalization on the ground that they take first and second person subject endings that coincide with the nominal 
possessive paradigm, rather than with the verbal subject paradigm. However, this distinction is only apparent because the verbal subject endings that do not coincide with their nominal possessive counterparts are clearly the result of innovations. Furthermore, when a subordinate verb is preceded by a direct object the latter must be marked for accusative case (2a), whereas the accusative case marker on direct objects that occupy a position immediately preceding a nominalized verb that is not part of a compound tense form is usually omitted (2b). ${ }^{27}$

a. mana čiwaku pla:nu-nči-ta aspi-pti-n-qa tapu-m not blackbird streetmap-4Poss ACc erase-s u B-3s Tapo-As s limaq ka-n-man ka-ra

Lima be-3s-рот be-3s.PAST

'If the blackbird had not erased our street-map, Tapo would have been Lima.'

(Tapo, Junín; Adelaar 1977: 98)

b. čay-ši kada tardi maripo:sa-qa ĉa-q miči:ru so-REP every afternoon butterfly-TOP arrive-3s.н A B wax-light upi-či-q extinguish-CAU S-AG.NMZ

'So it is said that the butterfly would go there every afternoon to extinguish the wax-light.'

(San Pedro de Cajas, Junín; Adelaar 1977: 412)

Subordinate verbs and switch reference play an important role in Quechuan narratives, because the use of subordinate verbs with the right switch-reference endings makes it possible to keep track of the actions of several non-SAP protagonists without having to name them again and again. This effect is strengthened by the practice of tail-head linkage that has been associated with switch reference in languages unrelated to Quechuan, for instance, in Papuan languages (de Vries 2005).

In the Aymaran languages, verbal subordination and switch reference are also present, but the use of subordinate verbs with a full range of personal reference markers encoding both subject and patient is limited to Jaqaru (cf. Hardman 2000: 72). Subordinate forms with subject marking only are preserved in Aymara varieties spoken in the northern part of the Bolivian department of Potosí (Briggs 1993: 288; Coler 2014: 627). Nonetheless, most other Aymara varieties do not encode personal reference in subordinate verbs at all, the only switch-reference marking being that between different subjects and same subjects. Both in Jaqaru and in the Aymara dialects that do encode person-of-subject in subordinate verbs, the forms in question look like nominalized verbs followed by nominal possessive endings and the locative case marker -na, for instance, Northern Potosí Aymara -iñana (1st), -imana (2nd), -ipana (3rd), -isana (4th, inclusive). ${ }^{28}$ 


\subsection{Nominalization and Verbalization}

Nominalization plays a central role in the morphosyntax of the main Andean languages. Nominalized verbs are used for, among other things, the construction of complement clauses, relative clauses and compound tenses. At the same time, nominalization also plays an important part in the formation of new lexical items, since nominalized verbs can acquire specialized lexical meanings as in any type of word derivation. Morphological verbalization is of comparable importance in the Aymaran languages, where it fills the function of copula verbs ('to be') and location verbs ('to be at', 'to belong to'), but less so in Quechuan where its role is essentially limited to lexical word formation.

In the Quechuan languages nominalization is compatible with personal reference marking involving both a subject and a patient. In other words, the subject-to-patient transitions with their characteristic affix combinations, which are essentially verbal in nature, can be transported to a nominalized context without any particular restrictions. Nevertheless, not all types of nominalization allow this. The infinitive nominalization in $-y$, for instance, cannot take personal reference markers that refer to subject and patient simultaneously. Therefore, personal reference markers that occur with the infinitive are best analysed as belonging to the nominal possessive set. This also holds true for nominalizations in the Aymaran languages, which are all incompatible with subject-to-patient transition. Only one subject or patient can be encoded, and the manner in which this is realized formally is the same as the way the possessor of a noun is indicated.

The number of nominalization procedures may differ among varieties, but all Aymaran and Quechuan languages minimally have a subjectcentred ('agentive') nominalizer, which is immune to time distinctions (Aymaran -iri, Quechuan -q). In addition, they have at least two non-subject centred nominalizers, one for events that are realized at the moment of reference or before (Aymara -ta, Quechuan -šqa / -sqa) and one for events that are expected to occur at any moment or after the moment of reference, including obligations (Aymara $-n^{y} a$, Quechuan $-n a$ ). ${ }^{29}$ In addition, the Quechuan nominalizer in -na is used for referring to instruments or places where an event normally takes place. ${ }^{30}$ The Quechuan languages also have an infinitive nominalizer (see above), which can be used to refer to the event itself. In Aymara, this function is covered by the nominalization in $-n^{y} a$.

Nominalized verb forms can act as verbal complements without any case marking or in combination with accusative case marking. As an example of the former, motion verbs, etc. can take an agentive form as their complement, which then indicates the purpose of the motion (3a). If the higher verb acts as an auxiliary verb (e.g. Quechuan muna- 'to want', ati 
(pa)- 'can', yača-/yaĉa- 'to know how to'), the complement is expressed by adding accusative case to an infinitive form (3b). If the subject of the verbal complement is different from that of the higher verb, one of the nonsubject nominalizers is used (3c.).

a. kal ${ }^{\mathrm{y}}$ pa-čka-n-ku kuči hapi-q run-PROG-3S-PLUR pig catch-AG.NMZ 'They are running to catch the pig.'

(Ayacucho Quechua; Soto Ruiz 1979: 334)

b. yača-nki-ču pučka-y-ta know-2s-INT spin-IN F-ACC 'Do you know how to spin?'

(Ayacucho Quechua: Soto Ruiz 1979: 190)

c. hatari-na-n-ta-m muna-ni get.up-F UT.N M Z-3 S-ACC-As s want-1S 'I want him to get up.'

(Ayacucho Quechua: Soto Ruiz 1979: 295)

Combinations of nominalized forms with oblique case markers are used to construct different types of adverbial clauses. In this way a Quechuan purpose construction consists in a combination of a future participle (non-realized non-subject-centred nominalizer) followed by the benefactive case marker -paq.

(4) aywa-mu-nki čay-ĉu lapa-nči mika-paku-na-nči-paq go-CIS-2 S.FU ( S C) that-LOC all-4 PO S S eat-P ROFIT-N MZ-4S-BEN 'You must come so we can all have something to eat there.'

(San Pedro de Cajas, Junín; Adelaar 1977: 408)

As noted above, verbalization is of particular importance in the inflectional morphology of the Aymaran languages. In Aymara the expression of the copula verb 'to be' is realized by means of the lengthening of a preceding vowel, which in this case also implies the blockage of any vowel suppression triggered by a following suffix (5).

(5) hani-w čača-:-k-i-ti

not-DECL man-COP.VBZ-INCOMPL-3S-NEG

'He is not a man.'

(Hardman et al. 1988: 239)

In the Muylaque dialect of Moquegua (Peru), described by Coler (2014: 4726 ), vowel length is no longer distinctive, leaving the presence of a vowel that would otherwise be suppressed as the only formal trace of the copula 'to be'. ${ }^{31}$ In the related Jaqaru language, the notion of copula 'to be' is expressed by a segmental affix -wa- (Hardman 2000: 48). 
The notion 'to be at' or 'to belong to' is expressed in Aymara by means of a verbalizing morpheme -ka-, identical in form to the Quechuan verb for 'to be' (also 'to be there', 'to exist'), which is then attached to a short form of the genitive/locative case marker $-n(a)$ - (6).

a. khaya-n-ka-s.k-i-wa

that.place-LOC-LOC.VBZ-PROG-3S-DECL

'He is over there.'

(Yapita 1991: 88)

b. huma-n-k-i-wa

yOu-LOC-LOC.VBZ-3S-DECL

'It is yours.'

(Yapita 1991: 3)

The extraordinary flexibility of the Aymaran languages in their use of verbalization and nominalization means that Aymaran words frequently contain several internal switches of word class (cf. Hardman et al. 1988: 266-8). In example (7) there are four such switches ( $>V, V>N, N>V, V>N)$. The same also occurs in Quechuan, although the options are less elaborate.

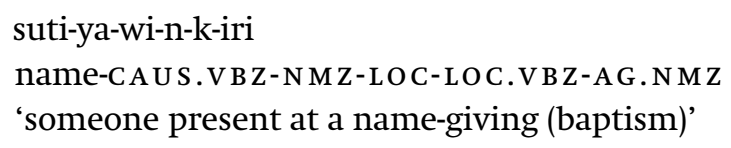

(Hardman et al. 1988: 268)

\subsection{Relative Clauses}

The formation of relative clauses is best documented for the Quechuan languages. There are at least two different strategies. The first and most common strategy implies the use of a nominalized verb to denote the main event in a relative clause; the second strategy involves a rather complex construction in which the relative clause contains a finite verb and is introduced by an interrogative pronoun, whereas the latter is semantically correlated with a demonstrative pronoun that introduces an accompanying superordinate clause. This construction is sometimes attributed to language contact with Spanish. However, it is particularly frequent in early colonial texts, where it appears to be strictly regulated. Furthermore, it may have been indispensable to the extent that it was the only way to express relative clauses with oblique antecedents (place, time, instrument, etc.).

When nominalized verbs act as the nucleus of a relative clause, they tend to follow rather than precede the antecedent. This is the case in Southern Quechua I when the nominalized verb is marked for person of 
the subject. In the Northern Junín varieties of this group, a type of nominalization in -nqa- occurs which is obligatorily marked for subject (and patient when relevant). It can be used in headless relative constructions, but when it is linked to an argument in the main clause, it must follow that argument. Both uses of the -nqa- nominalization are illustrated in the following example:

$$
\begin{aligned}
& \text { na:-mi serbi-ra-ma-nki sapatu qu-nqa-q uša-nqa-n-gama } \\
& \text { already-A s s serve-P E R F-10-2s shoe give-N M z-1>2 finish-N MZ-3 s-L I M } \\
& \text { 'You have already served me long enough to wear out the shoes that } \\
& \text { I gave to you.' }
\end{aligned}
$$

(Tarma Quechua; Adelaar 1977: 115)

Case markers and clitics that would normally follow the head of a noun phrase, in casu, the antecedent, are attached to the nominalized verb that fills the relative clause to its right. In example (9) from Cuzco Quechua, the topic marker -qa is attached to the nominalized verb filling the relative clause, which itself follows the antecedent. Nevertheless, part of the relative clause is located to the left of the antecedent.

(9) Juan-pa waka ranti-sqa-n-qa yuraq-mi ka-rqa-n

Juan-GEN cow buy-N Mz-3S-Top white-Ass be-PAST-3S

'The cow that Juan bought was white.'

(Hastings 2002, cited in Coler 2014: 620)

\subsection{Possession and Ownership}

In a possessive construction involving the lexical expression of a possessor and a possessed, both the former and the latter are morphologically marked. The possessor precedes the possessed and takes genitive case marking, whereas the possessed is marked for the person of the possessor. This rule of double marking holds for both the Aymaran and the Quechuan languages (except Ecuadorian Quichua). The example in (11) illustrates two such relations.

(10) Mariya- $\chi$ naya-n kul ${ }^{y}$ aka-ha-wa

María-T OP I-GEN sister-1 P os S-DEC L

'María is my sister.'

(Aymara; Yapita 1991: 2)

$\mathrm{n}^{\mathrm{y}}$ uqa-pa wasi-y-pa punku-n

I-GEN house-1 Poss-GEN door-3 Poss

'The door of my house'

(Ayacucho Quechua; Soto Ruiz 1979: 95) 
A very frequent way to indicate possession is by means of a nominal suffix -yuq (Quechuan) or -ni (Aymaran), which denotes ownership or pertinence. It can be used with substantives and nominalized verbs and is frequently found in place names (e.g. wanka-yuq 'place with a big boulder'; mana tayta$y u q$ 'having no father', 'orphan'). Affixes with the opposite meaning 'without', 'not having' are sporadically preserved in Quechuan dialects.

\subsection{Negation and Interrogation}

In the Aymaran and Quechuan languages, negation is normally expressed at the sentence level by means of two discontinuous components. The first element, a negative adverb, is located (not necessarily immediately) before the negated sentence part, whereas the second element, a specialized clitic, appears after the sentence part that is negated or after the predicate, when the domain of the negation coincides with the whole sentence. In syntactic collocations that are lower than the sentence level, such as subordinate clauses, nominalizations or negated lexical items, the adverb is used without the clitic. The negative adverb in Quechuan is mana in statements but ama in prohibitions, apprehensions or negative suggestions; in Aymara the negation marker is hani, and its Jaqaru counterpart is $i \check{s} a$. The clitic that closes a negation at the sentence level is -ču in most Quechuan varieties and -ti in Aymara (- $t^{y} i$ in Jaqaru).

In both language groups the use of negation at the sentence level can affect the morphological make-up of the main verb in a sentence. In the Quechua of Tarma province (Northern Junín), it requires the absence of verb-internal affixes referring to aspect. ${ }^{32}$ By contrast, in Aymara the use of an affix -ka- denoting incompletive ('yet') is obligatory in negative statements.

(12) hani-w alha- Ø-ka-tayna-ti

not-DECL alfalfa-COP.VBZ-INCOMPL-3S.REMOTE-NEG

'It was not alfalfa ...'

(Coler 2014: 384)

Polar interrogative sentences are characterized by the presence of an interrogative clitic, which in most Aymaran and Quechuan languages is identical in form to the negative clitic (-ti in Aymara, -ču in Quechuan). However, some Quechua I dialects have special forms for this purpose, namely, -ku in Ancash Quechua and -čun in Huanca Quechua. ${ }^{33}$ The interrogative clitic is attached to the constituent of the sentence on which the interrogation is focused or in default of it to the predicate. Negative questions are formed by attaching an interrogative clitic to the negative adverb.

Interrogative pronouns, verbs or adverbs in content questions occupy the initial position in a sentence. They are usually followed by clitics that 
either are neutral or express (a lack of) confidence in the answer the addressee is able to give. In the absence of a specialized category of negative pronouns, interrogative pronouns followed by an inclusive clitic (-pas, -pis, -si in Quechuan; -sa in Aymara; meaning 'even') are used to express absolute negation in a negative grammatical context, as in the following example from Tarma Quechua (cf. note 31)

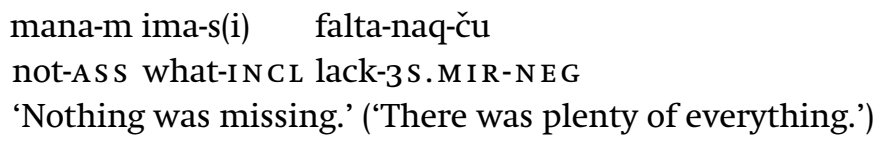

\subsection{Evidentials}

Evidentiality (cf. Aikhenvald 2004) plays an important role in both the Aymaran and the Quechuan languages, but the way in which evidentiality marking is organized in each of the two language groups is rather different. When most of the descriptive work on Andean languages was produced (between 1965 and 1990), the notion of evidentiality (resp. evidentials) was not yet widely known. So terms such as data source and validation (resp. validators) were used instead. Hardman (1972) highlights the cultural essentiality of using the right data source indications in Aymara.

Evidentiality marking in the Quechuan languages is normally based on a three-way distinction comprising categories that can be defined as assertive $-m(i)$, reportative $-\check{s}(i)$ and conjectural $-\hat{c}(i)$ (Quechua I) or $-\check{c}(a)$ (Quechua IIC). Some varieties, such as Ayacucho Quechua and South Conchucos Quechua (Hintz and Hintz forthcoming) have developed more elaborate systems with additional distinctions. In Ayacucho Quechua, for instance, the evidential markers can be extended with an element -iki, indicating that the addressee is believed to have access to the same sources of information as the speaker him/herself (cf. Soto Ruiz 1979: 199-201).

$$
\begin{aligned}
& \text { yanapa-saq-m-iki, } \quad \text { pay sapa wata yanapa-wa-n } \\
& \text { help-1S.F U T-ASS-IN TE R ACT IVE he every year help-10-3s } \\
& \text { 'As you can understand, I will help him. He helps me out every year.' }
\end{aligned}
$$

(Soto Ruiz 1979: 200)

The evidential markers are not exclusively used for the identification of a data source. Although the assertive is sometimes described as a marker of first-hand information, it is also used for general statements and for events still to occur, which the speaker could not have personally witnessed. Essential is that the speaker has good personal reasons to be convinced of what (s)he is saying, a position which has been characterized by Faller (2002) as 'Best Possible Grounds'. The reportative is not normally used for 
quotes by known persons, but for rumours and cases of reported knowledge from undetermined sources for which the speaker declines any responsibility.

In most Quechuan languages, evidential markers also fulfil a syntactic function. Since they are mutually exclusive, the presence of one of them marks a stretch of speech as a full sentence or its syntactic equivalent. For instance, in mana-m 'no!' the presence of the assertive indicates that this expression occupies the place of a sentence. In narratives the evidential markers regularly appear after the first available constituent in a sentence (unless a particular clitic, such as the Topic marker -qa, already occupies that slot). Only in conversations and dialogues involving questions and answers may they move to the part of the sentence which is in focus. With nominal predicates accompanied by the verb 'to be' (or the absence of it when the subject is third person), the use of an evidential marker is compulsory. Nevertheless, sentences which do not contain an evidential marker are rare in careful speech.

In Aymara the clitic -wa, which resembles the Quechuan assertive in its syntactic functions, does not seem to be part of an evidential system. It functions as a declarative marker in statements, as opposed to questions, commands and conjectures (Coler 2014: 535-42). The reportative function is conveyed by a separate lexical expression $s-i-w(a)$ 'he/she/it says', which incidentally contains the same declarative marker. ${ }^{34}$ Conjecture and inference are expressed within the verb itself to the left of tense-and-mood markers.

$$
\begin{array}{llll}
\text { uka-t } & \text { may.ni } & \text { hilata-pa-mpi- } \chi & \text { un }^{\mathrm{y}} \mathrm{i} . \mathrm{s}-\check{c}(\mathrm{i})-\mathrm{i} \\
\text { that-AB L } & \text { other } & \text { brother-3Poss-com-то } & \text { envy-conJ-3s }
\end{array}
$$

'And so he must have envied his other brother[.]'

(Coler 2014: 448)

\subsection{Quotation}

Direct quotations play a central role in Andean discourse. They are normally followed by a subordinate same subjects form of the verb 'to say' (ni-r in Quechua I, ni-spa in Quechua II; sa-s(a) in Aymara), which functions as a sort of lexical quotation mark. As a rule, all verbs of communication, including the verb 'to say' itself, occur in combination with such a form. They cannot be combined with the quotation directly.

Direct quotations are constructed according to the perspective of the person whose speech is represented. They take all the personal reference markers that would occur in a real speech situation. There is no replacement of Speech Act Participants by third person, for instance. It is noteworthy that the verb 'to say', at least in Quechuan, covers a wide range of 
semantic possibilities. It can also convey the meaning of 'to think', 'to believe', 'to consider', etc., which forces the speaker to imagine a speech situation that does not really exist.

Also in Quechuan, the quotation procedure is kept strictly distinct from the reportative, and the two categories can easily be combined. There are reported quotes (and quoted reports), as in the following example from Ayacucho (16).

\begin{tabular}{|c|c|c|}
\hline “lyiw $\quad \mathrm{al}^{\mathrm{y}}$ pa-kuna-m & qam-kuna-paq & ka-nqa" \\
\hline land-PLUR-ASS & you-PLUR-BEN & be-3s.FuT \\
\hline ni-spa-s-iki & kanan-qa & ni-wa-čka-nčik \\
\hline Say-S U B-REP-INTERACTIVE & nOW-T OP & say-1O.INV-PROG-4S \\
\hline Reportedly, as you know wel & & $\begin{array}{l}\text { us that all the land } \\
\text { they are saying to } \\
\text { 95) }\end{array}$ \\
\hline
\end{tabular}

\subsection{Topic and Focus}

Sentence constituents that contain 'old' information or information not in focus are frequently followed by a clitic that has nearly the same form in both language groups and almost certainly the same origin. This topicalizing clitic, which is $-q a$ in Quechuan (pronounced $-\chi a$, $-q a$ or $-k a$ depending on the variety), $-\chi a$ in Aymara and -qa in Jaqaru, can occur several times in a sentence but usually before the verb or the sentence constituent in focus. Nonetheless, it can also occur after a verb or sentence constituent in focus, where it indicates an afterthought or an element that has been removed from its natural syntactic environment. When -qal- $\chi a$ is attached to a finite verb or a sentence predicate, it usually indicates a contrast between two sentences and is not related to the internal structure of either of the two sentences. Coler (2014: 533-5) notes that in the Muylaque dialect of Aymara the function of this clitic has become very much eroded and that there is a tendency for it to be attached as a default marker to all the main constituents of a sentence (including the verb) except for the one that contains the declarative marker - wa (see above).

In Quechuan the interplay between the topic marker and the evidential markers $-m(i)$ and $-s(i)$, which can be used to highlight the focus of a sentence, may cause the suggestion that these affixes in combination represent some sort of topic-comment articulation. This is only partly true, however, because the evidential markers are not necessarily linked to the focus (see above). It is mainly the case in dialogues with an interchange of questions and answers. In the following (constructed) examples from Ayacucho Quechua, a neutral constellation with only an obligatory 
evidential but no topic marker (17a) is contrasted with a construction in which both the topic marker and an evidential occur (17b).

a. kay-mi qiqa

this-A s s chalk

'This is a piece of chalk.'

b. kay-qa qiqa-m

this-T op chalk-A s $S$

'As for this, it is a piece of chalk.'

\subsection{Deixis}

Most Quechuan languages have a rather straightforward system of demonstratives with a three-way distinction of distance: kay 'this', čay 'that', wak (Ayacucho, North Junín) / taqay (Ancash) / haqay ̌̌aq ${ }^{h} a y$ (Cuzco, Bolivia) 'that over there'. One of the main sub-branches of the Quechuan family, Quechua IIB, has a more limited system with only a two-way distinction (kay, čay). As a unique case, the archaic Quechua dialect of Pacaraos in the Upper Chancay valley (Lima, Peru) features an inventory of six demonstratives, which encodes relative altitude at a distant location: kay 'this', čay 'that', kuy 'that over there', ĉuqay 'that distant and level', ĉaqay 'that distant and lower', naqay 'that distant and higher'. In the Aymaran family, Jaqaru features a three-way distinction ( $\left.a k a, u k a, k^{h} u w a\right)$ and Aymara a four-way distinction ( $\left.a k a, u k a, k^{h} a y a, k^{h} u r i\right)$.

In the Andean languages demonstratives can be used independently (as pronouns) or attributively (as adjectives). An interesting feature of the Andean demonstratives in their attributive function is that, like interrogative pronouns, they are sensitive to time and space distinctions. For instance, Quechuan kanan/kunan 'now' has a demonstrative function when used attributively with nouns referring to time, as in kunan wata 'this year' (not *kay wata), whereas the interrogative pronoun may 'what place', 'where' replaces ima 'what' in a construction with a noun referring to a location, as in may $l^{y} a q t a$, rather than *ima $l^{y} a q t a$ 'which town'.

Deixis also plays a significant role in the verbal morphosyntax of the Andean languages. In the Quechuan languages and in Aymara, verbs of motion (or, better, verbs involving a change of location) must be specified for whether or not the motion they express is directed or oriented towards the speaker (with a verb-internal suffix -mu- in Quechuan and -ni- in Aymara). ${ }^{35}$ Absence of this suffix implies that the movement is not directed or oriented at the speaker. With verbs that do not express a motion, -mu- is used optionally in order to point at a location where an event will take place with consequences for the Speech Act Participants at the place of speaking. It usually indicates that the subject of the motion will go to the indicated place to perform an action and then will come back. Cuzco 
Quechua has developed a verbal suffix -pu-, which apart from benefactive also indicates a definitive motion away from the speaker. In Aymara there is a verbal suffix -waya- that indicates a circular movement away from the location of speaker and then back to it.

Orthographic conventions:

\begin{tabular}{|c|c|}
\hline c $\hat{s}:$ & retroflex affricate and sibilant \\
\hline č š: & alveo-palatal affricate and sibilant \\
\hline $\mathrm{n}^{\mathrm{y}}, \mathrm{1}^{\mathrm{y}}, \mathrm{t}^{\mathrm{y}}:$ & palatalized sounds \\
\hline y: & palatal glide \\
\hline q. & $\begin{array}{l}\text { voiceless uvular (post-velar) stop [often realized as fri- } \\
\text { cative in Quechuan, almost always fricative in sylla- } \\
\text { ble-final position] }\end{array}$ \\
\hline & voiceless uvular (post-velar) fricative \\
\hline : & voiceless velar fricative \\
\hline h: & $\begin{array}{l}\text { voiceless velar fricative in variation with voiceless } \\
\text { glottal }[\mathrm{x} \sim \mathrm{h}]\end{array}$ \\
\hline$::$ & long vowel a \\
\hline$\ddot{*}$ & $\begin{array}{l}\text { tap r [affricated word-finally, sometimes also word- } \\
\text { initially] }\end{array}$ \\
\hline ', k', t', q', etc.: & ejectives, glottalized consonants \\
\hline $\mathrm{p}^{\mathrm{h}}, \mathrm{k}^{\mathrm{h}}, \mathrm{t}^{\mathrm{h}}, \mathrm{q}^{\mathrm{h}}$, etc.: & aspirated consonants \\
\hline & alveolar nasal [velar nasal word-finally] \\
\hline $\mathrm{u}:$ & $\begin{array}{l}\text { high vowels are realized as mid vowels in the neigh- } \\
\text { bourhood of uvular consonants }\end{array}$ \\
\hline
\end{tabular}

\section{Notes}

1. The research leading to this chapter has received funding from the European Research Council under the European Union's Seventh Framework Programme (FP7/2007-2013) / ERC grant agreement $\mathrm{n}^{\circ}$ 295918.

2. Hardman (1978) distinguishes two different languages: Jaqaru and Kawki. In their present-day form, the two varieties are very similar.

3. The spelling 'Aimara', preferred by Cerron-Palomino (2000), is preserved in this instance.

4. On-going research by Nick Emlen has demonstrated that the phonotactic differences between the Aymaran and Quechuan proto-languages become more outspoken as one removes the possible effects of language contact between the two families; nevertheless, many similarities remain even then, particularly, in the reconstructed phonemic inventories (Emlen forthcoming).

5. Awa Pit speakers in Ecuador are recent migrants from Colombia. 
6. The last recorded Cholón speakers were settled on the Huallaga River in the Amazonian lowlands of Eastern Peru. However, toponymy suggests that the Hibito-Cholón family, to which this language belongs, extended into the Andean highlands of Cajamarca (Northern Peru) until early colonial times.

7. Similarities with Turkic and other Altaic languages have repeatedly been noticed.

8. This branch is usually referred to as Quechua I, following the terminology introduced by Torero (1964). The remaining Quechuan languages are jointly denominated Quechua II.

9. It is only found in Quechuan dialects with a relatively recent Aymara substratum, such as Puno Quechua, which have borrowed Aymara affixes with the accompanying vowel suppression rules (cf. Adelaar 1987).

10. Some indefinite pronouns obligatorily take possessive personal reference suffixes (e.g. Quechuan $l^{y} a p a-$ 'all').

11. Originally $-(k) t a$, which is attested in historical texts and in at least two modern dialects.

12. In Jaqaru a suffix tha has been recorded for the accusative (Hardman 2000: 15); in many cases, however, a direct object appears to remain unmarked.

13. This general observation may not necessarily be founded on a detailed survey of local practice. The geographical distribution could be more complex. Whether or not contact with Spanish is responsible for the use of man to denote indirect objects (presumably, as a translation of Spanish ' $a$ ') remains to be established.

14. A derivational passive in -ytuku- (possibly derived from a periphrastic construction, Infinitive $-y+t u k u$ - 'to become') has been found in Ecuador and in some early colonial Quechua sources. It is absent from most modern Quechuan dialects, and its origin (whether indigenous or induced by contact) remains obscure.

15. A similar work division is found in Aymaran between the allative marker -ru and the accusative (see above).

16. Case markers formed by combining other case markers are also found in languages of the Eastern Andean slopes (e.g. in Cholón, cf. Alexander-Bakkerus 2005).

17. In some Quechua I varieties (Ancash, Huanca, Pacaraos), a special ablative marker -piq alternates with -piqta without any difference in meaning.

18. The endings that involve the expression of a patient are often referred to as 'transitions' (transiciones) in the traditional literature on Andean languages.

19. As in the case of -ma(:)-|-wa-, the distinction between -šu- and -su- is geographically determined. 
20. In Adelaar (2013) we have proposed the term 'revelative' as a possible denomination for this category.

21. There are special portmanteau forms for the (inclusive) fourth person and for the second person in the Southern Peruvian Quechua IIC dialects. A shared origin of the Potential affix -man with the allative case marker is likely but not proven.

22. 'Non-involver' in Hardman et al. (1988).

23. Progressive aspect is $k u$ - or $-x u$ - in Ecuador (originally from the reflexive marker $-k u$-).

24. The semantic range represented by the perfective in Southern Quechua I is very similar to that of perfective aspect in Russian.

25. This rich variation is also obscured by the preference, especially in the older descriptive literature, for one-line definitions that reflect a monolithic meaning supposed to be applicable to several or all varieties of Quechuan.

26. Following a tradition from Altaic studies, the term 'converb' has also been used for referring to the Quechuan subordinate verbs (e.g. Bruil 2008).

27. This behaviour of direct objects before nominalized verbs may have been copied from the practice of nominal composition (by juxtaposition).

28. It should be noted, however, that there is no nominalizing affix relatable to - $i$ in Aymaran, unlike in Quechuan, where the Infinitive ends in $-y$.

29. In sixteenth-century Quechua II, there was an alternative form -nqa for -na. It is still preserved in Ecuadorian Quechua as -nga.

30. For the latter function, Aymaran also has a specific marker -wi, which is frequently used in place names.

31. Cerrón-Palomino (2008: 200-1) derives the verbal lengthening in Aymara from a reconstructed copula verb formally identical to the Quechuan verb ka- 'to be'.

32. In Adelaar (2013) we stated that in Tarma Quechua negation is also incompatible with verbs in the mirative or sudden discovery tense. This holds true to the extent that there is a tendency to use verbs in the regular past tense instead. However, if the negative statement conveys an essentially positive message, use of the mirative or sudden discovery tense is not prohibited, as in mana-m ima-si falta-naq-ču 'nothing was lacking', or in other words, 'everything you can imagine was there', 'there was plenty of everything' (cf. Adelaar 1977: 210).

33. Nevertheless, $-\check{c} u$ is used in Huanca before the evidential clitics $-\hat{c}$ (conjectural) and - $\hat{s}$ (reportative) (Cerrón-Palomino 1976: 232).

34. The Jaqaru language has a reportative marker -mna, which is used as a clitic (Hardman 2000: 92).

35. Strangely, this highly productive suffix -ni- is not attested in Jaqaru. 


\section{References}

Adelaar, Willem F. H. 1977. Tarma Quechua: Grammar, texts, dictionary. Lisse: The Peter de Ridder Press.

1986. La relación quechua-aru. Perspectivas para la separación del léxico. Revista Andina 4(2): 379-426.

1987. Aymarismos en el quechua de Puno. INDIANA 11: 223-31.

1988. Categorías de aspecto en el quechua del Perú central (English text). Amerindia 13: 15-41.

1995. Raíces lingüísticas del quichua de Santiago del Estero. In Ana Fernández Garay and José Pedro Viegas Barros (eds.), Actas II Jornadas de Lingüística Aborigen (Buenos Aires, 14-18 November 1994), pp. 25-50. Universidad de Buenos Aires, Facultad de Filosofía y Letras, Instituto de Lingüística.

2012. Modeling convergence: Towards a reconstruction of the history of Quechuan-Aymaran interaction. LINGUA 122(5): 461-9.

2013. A Quechuan Mirative? In Alexandra Y. Aikhenvald and Anne Storch (eds.), Perception and cognition in language and culture, pp. 95109. Leiden and Boston: Brill.

Adelaar, Willem F. H. and Pieter C. Muysken. 2004. The languages of the Andes. Cambridge University Press.

Aikhenvald, Alexandra Y. 2004. Evidentiality. Oxford University Press.

Alexander-Bakkerus, Astrid. 2005. Eighteenth-century Cholón. Utrecht: Netherlands Graduate School of Linguistics (LOT).

Beresford-Jones, David and Paul Heggarty. 2012. Broadening our horizons: Towards an interdisciplinary prehistory of the Andes. In Paul Heggarty and David Beresford-Jones (eds.), Archaeology and language in the Andes: A cross-disciplinary exploration of prehistory, pp. 57-84. (Proceedings of the British Academy 173). Oxford and New York: Oxford University Press.

Bills, Garland D., Rudolph C. Troike, and C. Bernardo Vallejo. 1969. An introduction to spoken Bolivian Quechua. Special publication of the Institute of Latin American Studies, University of Texas at Austin. University of Texas Press.

Briggs, Lucy Th. 1993. El Idioma Aymara: variantes regionales y sociales. La Paz: Ediciones ILCA.

Bruil, Martine. 2008. Innovations in the Ecuadorian Converb Systems: Grammatical change in language contact situations. MPhil. and MA thesis, Faculty of Humanities, Leiden University.

Burger, Richard L. 2008. Chavín de Huántar and its sphere of influence. In Helaine Silverman and William Isbell (eds.), Handbook of South American archaeology, pp. 681-703. Berlin: Springer.

2012. Central Andean language expansion and the Chavín sphere of interaction. In Paul Heggarty and David Beresford Jones (eds.), Archaeology and language in the Andes: A cross-disciplinary exploration of 
prehistory, pp. 135-61. (Proceedings of the British Academy 173). Oxford and New York: Oxford University Press.

Cerrón-Palomino, Rodolfo M. 1976. Gramática Quechua Junín-Huanca. Lima:

Ministerio de Educación e Instituto de Estudios Peruanos.

1987. Lingüística Quechua. Cuzco: Centro de Estudios Regionales Andinos

'Bartolomé de Las Casas'.

2000. Lingüística Aimara. Lima: Centro de Estudios Regionales Andinos

'Bartolomé de Las Casas'.

2006. El Chipaya o la Lengua de los Hombres del Agua. Lima: Fondo Editorial de la Pontificia Universidad Católica del Perú.

2008. Quechumara: Estructuras paralelas del quechua y del aimara. La Paz: Universidad Mayor de San Simón, PROEIB Andes, and Plural Editores. Cerrón-Palomino, Rodolfo M., Enrique Ballón Aguirre. 2011. Chipaya: Léxico Etnotaxonomía. Nijmegen: Center for Language Studies, Radboud University; Lima: Fondo Editorial de la Pontificia Universidad Católica del Perú.

Ciucci, Luca and Pieter C. Muysken. 2011. Hernando de Alcocer y la Breve declaración del Arte y Bocabulario de lengua del Ynga conforme al estilo y su vso de la provincia de Quito: El más antiguo manuscrito de quichua del Ecuador INDIANA 28: 359-93.

Coler, Matt. 2014. A grammar of Muylaq' Aymara. Leiden and Boston: Brill.

Emlen, Nicholas Q. Forthcoming. Perspectives on the Quechua-Aymara contact relationship and the lexicon and phonology of Pre-ProtoAymara. International Journal of American Linguistics.

Faller, Martina. 2002. Semantics and pragmatics of evidentials in Cuzco Quechua. $\mathrm{PhD}$ dissertation, Stanford University.

Hardman, Martha J. 1966. Jaqaru: Outline of phonological and morphological structure. The Hague and Paris: Mouton.

1972. Postulados lingüísticos del idioma aymara. In Alberto Escobar (ed.), El reto del multilingüismo en el Perú, pp. 37-43. Lima: Instituto de Estudios Peruanos.

1978. Jaqi: The linguistic family. International Journal of American Linguistics 44(2): 146-53.

2000. Jaqaru. Munich: Lincom Europa.

Hardman, Martha, Juana Vásquez and Juan de Dios Yapita. 1988. Aymara: Compendio de estructura fonológica y gramatical. La Paz: Instituto de Lengua y Cultura Aymara; Gainesville, FL: The Aymara Foundation.

Hastings, Rachel. 2002. The interpretation of Cuzco Quechua relative clauses. In Ji-Yung Kim and Adam Werle (eds.), Proceedings of SULA, pp. 53-62. (University of Massachusetts Occasional Papers 25). Amherst, MA: GLSA Publications.

Hintz, Daniel J. 2011. Crossing aspectual frontiers: Emergence, evolution, and interwoven semantic domains in South Conchucos Quechua discourse. (University of California Publications in Linguistics 146). Berkeley and Los Angeles: University of California Press. 
Hintz, Diane M. 2007. Past tense forms and their functions in South Conchucos Quechua: Time, evidentiality, discourse structure, and affect. PhD dissertation, University of California, Santa Barbara.

Hintz, Daniel J. and Diane M. Hintz. Forthcoming. The evidential category of mutual knowledge in Quechua. To appear in LINGUA.

Mann, Charles C. 2005. 1491: New revelations of the Americas before Columbus. New York: Alfred A. Knopf.

Moseley, Michael. 2001. The Incas and their ancestors. Revised edn. London: Thames \& Hudson.

Muysken, Pieter C. 2012. Modelling the Quechua-Aymara relationship: Structural features, sociolinguistic scenarios and possible archaeological evidence. In Paul Heggarty and David Beresford Jones (eds.), Archaeology and language in the Andes: A cross-disciplinary exploration of prehistory, pp. 85-109. (Proceedings of the British Academy 173). Oxford and New York: Oxford University Press.

Orr, Carolyn J. and Robert E. Longacre. 1968. Proto Quechumaran. Language 44: 28-55.

Parker, Gary J. 1973. Derivación verbal en el quechua de Ancash. (Documento de Trabajo no. 25). Lima: Universidad Nacional Mayor de San Marcos, Centro de Investigación de Lingüística Aplicada.

1976. Gramática quechua Ancash-Huailas. Lima: Ministerio de Educación and Instituto de Estudios Peruanos.

Quesada Castillo, Félix. 1976. Gramática quechua Cajamarca-Cañaris. Lima: Ministerio de Educación and Instituto de Estudios Peruanos.

Soto Ruiz, Clodoaldo. 1979. Quechua: Manual de Enseñanza. Lima: Instituto de Estudios Peruanos.

Torero Fernández de Córdova, Alfredo A. 1964. Los dialectos quechuas. Anales Científicos de la Universidad Agraria 2(4): 446-78. Lima: La Molina. 1972. Lingüística e historia de la sociedad andina. In Alberto Escobar (ed.), El reto del multilingüismo en el Perú, pp. 46-106. Lima: Instituto de Estudios Peruanos.

2002. Idiomas de los Andes: Lingüística e Historia. Lima: Editorial Horizonte.

Vries, Lourens de. 2005. Towards a typology of tail-head linkage in Papuan languages. Studies in Language 29(2): 363-84.

Yapita Moya, Juan de Dios. 1991. Curso de Aymara Paceño. Institute of Amerindian Studies, University of St Andrews. 